[Radiocarbon, Vol. 13, No. 2, 1971, P. 420-431]

\title{
RHODESIAN RADIOCARBON MEASUREMENTS IV
}

\section{J. G. SHEPPARD and E. R. SWART}

Department of Chemistry, University of Rhodesia, Salisbury, Rhodesia

The following list of dates was compiled since 1967 (R., 1967, v. 9, p. 382-386). Procedures of measurements are essentially unchanged from those reported previously (R., 1964, v. 6, p. 31-36; 1966, v. 8, p. 423-429). The only major change in procedure is that the practice adopted in previous date lists of widening the errors due to fluctuations in $\mathrm{C}^{14}$ content of the exchange reservoir has been discontinued. This leaves the users free to apply the necessary corrections as they become available, e.g., Stuiver and Suess (1966) and Ralph and Michael (1969). The two gas proportional counters were rebuilt in 1968. It was found that outgassing the polytetrafluoroethylene insulators at $100^{\circ} \mathrm{C}$ under vacuum for 48 hours prior to reassembling the counters considerably hastened attainment of stable operating conditions.

\section{SAMPLE DESCRIPTIONS}

I. ARCHAEOLOGIC SAMPLES

\section{A. Malawi}

\section{SR-127. Chowo Rock, Nyika Plateau}

Charcoal from occupation deposit 31 to $46 \mathrm{~cm}$ below surface Mwavarambo pottery also occurred in upper $31 \mathrm{~cm}$ of deposit $\left(10^{\circ} 45^{\prime} \mathrm{S}\right.$ Lat, $33^{\circ} 45^{\prime}$ E Long). Coll. and subm. by K. R. Robinson, P. O. Box 170, Bulawayo, Rhodesia. Comment: date marks end of Later Stone age at Chowo Rock.

\section{SR-178. Mawudzu Hill}

$$
470 \pm 95
$$

Charcoal from 41 to $51 \mathrm{~cm}$ level (14 $15^{\prime} \mathrm{S}$ Lat, $35^{\circ} 05^{\prime} \mathrm{E}$ Long). Coll. and subm. by K. R. Robinson. Comment: sample is from Iron age site, being investigated in $\mathrm{N}$ Malawi in an effort to confirm work done in 1965-66.

\section{SR-174. Nkope Hill}

$1590 \pm 120$

Charcoal from 51 to $71 \mathrm{~cm}$ depth in assoc. with Early Iron age pottery ( $14^{\circ} 12^{\prime} \mathrm{S}$ Lat, $35^{\circ} 02^{\prime} \mathrm{E}$ Long). Coll. and subm. by K. R. Robinson. Comment: date is average for Early Iron age stratum at site.

\section{SR-175. Nkope Hill}

$1175 \pm 100$

Charcoal from 61 to $81 \mathrm{~cm}$ level. Coll. and subm. by K. R. Robinson.

\section{SR-128. Phopo Hill, Lake Kazuni}

$1655 \pm 95$

Charcoal from $23 \mathrm{~cm}$ below surface in a midden patch assoc. with 
Mwavarambo pottery sherds $\left(11^{\circ} 07^{\prime} \mathrm{S}\right.$ Lat, $33^{\circ} 39^{\prime} \mathrm{E}$ Long). Coll. and subm. by K. R. Robinson. Comment: date confirms early origin of Mwavarambo pottery in $\mathrm{N}$ Malawi.

\section{SR-148. Phopo Hill, Lake Kazuni}

$1745 \pm 170$

Charcoal from 51 to $66 \mathrm{~cm}$ below surface of midden deposit containing sherds and bone. Coll. and subm. by K. R. Robinson. Comment: pottery is Mwavarambo ware; the only other date the submitter has for similar pottery is A.D. 1250 (UCLA-1242, R., 1968, v. 10, p. 155). Pottery was found at Karonga, Malawi.

\section{SR-161. Phopo Hill, Lake Kazuni}

$1445 \pm 120$

Charcoal from 31 to $46 \mathrm{~cm}$ below surface assoc. with sherds and bone.

\section{SR-145. Rock shelter on Hora Mt.}

$$
\begin{aligned}
& 16,680 \pm 180 \\
& 14,730 \text { в.c. }
\end{aligned}
$$

Charcoal from 51 to $71 \mathrm{~cm}$ below surface assoc. with artifacts of white quartz ( $11^{\circ} 40^{\prime} \mathrm{S}$ Lat, $33^{\circ} 38^{\prime} \mathrm{E}$ Long). Coll. and subm. by K. R. Robinson. Comment: a further date from a series of sites being investigated in N Malawi.

\section{SR-147. Lumbule Hill, Livingstonia}

$1385 \pm 100$

Charcoal from 61 to $76 \mathrm{~cm}$ below surface in occupation deposit containing sherds and iron ( $11^{\circ} 0^{\prime} \mathrm{S}$ Lat, $33^{\circ} 30^{\prime} \mathrm{E}$ Long). Coll. and subm. by K. R. Robinson. Comment: pottery is Mwavarambo ware as at Phopo Hill.

\section{B. Rhodesia}

\section{Chedzurgwe series, Urungwe Dist., Karoi}

The site, a large village, contains abundant pottery, copper ingots and other artifacts closely resembling those from Ingome Ilede $113 \mathrm{~km}$ to the NW (16 $47^{\prime} \mathrm{S}$ Lat, $29^{\circ} 37^{\prime} \mathrm{E}$ Long). Coll. and subm. by P. S. Garlake, Natl. Monuments Comm., Salisbury, Rhodesia. Comment: see R., 1966, v. 8, p. 424 for other Ingombe Ilede dates, and Garlake (1970).

SR-162. Chedzurgwe

Charcoal sample from 11 to $20 \mathrm{~cm}$ below surface.

SR-177. Chedzurgwe

Charcoal from 10 to $15 \mathrm{~cm}$.

SR-179. Chedzurgwe

Charcoal from 5 to $10 \mathrm{~cm}$.

SR-180. Chedzurgwe

Charcoal from 8 to $15 \mathrm{~cm}$.
A.D. 1740

$$
210 \pm 90
$$

$$
415 \pm 120
$$

A.D. 1535

A.D. 1600

$$
350 \pm 120
$$

$550 \pm 95$ 


\section{SR-163.}

$$
840 \pm 95
$$

Charcoal from Early Iron age village site, from surface of a daga floor which has been sealed by daga from a hut collapse $\left(16^{\circ} 51^{\prime} \mathrm{S}\right.$ Lat, $30^{\circ} 50^{\prime} \mathrm{E}$ Long). Coll. and subm. by P. S. Garlake. Comment: sample assoc. with pottery at this site, in an area where little archaeol. field work has been done.

\section{SR-119. Cighwa Hill, Chibi Reserve}

$1540 \pm 95$

Charcoal from test pit excavated at ancient occupation site hidden within a natural enclosure formed by granite hills $\left(20^{\circ} 21^{\prime} \mathrm{S}\right.$ Lat, $30^{\circ} 53^{\prime}$ E Long). Pottery was of early Iron age tradition. Typologically, A.D. 410 is acceptable. Coll. and subm. by K. R. Robinson. Comment: see Robinson (1967).

\section{SR-140. Gaika Gold Mine, Que Que}

Modern

Carbonized wood from $12 \mathrm{~m}$ below surface in ancient mine. Sample too recent to date $\left(18^{\circ} 53^{\prime} \mathrm{S}\right.$ Lat, $29^{\circ} 45^{\prime} \mathrm{E}$ Long). Coll. by W. J. Vowles and subm. by R. Summers, both of Natl. Mus., Bulawayo, Rhodesia. Comment: direct historical evidence shows that nobody was living in Que Que area in 1868. Measurement shows that the mine was being worked up to the last moment and was not abandoned by ancient workers as unprofitable. Despite apparently negative result, sample provides important information.

\section{SR-143. Geelong Gold Mine, Gwanda}

$780 \pm 95$

Charred wood from a firesetting $24 \mathrm{~m}$ below surface in filling of an ancient mine (21 $1^{\circ} 0^{\prime} \mathrm{S}$ Lat, $29^{\circ} 18^{\prime} \mathrm{E}$ Long). Coll. and subm. by R. Summers. Comment: result falls within range of Samples SR-44, 53, and 58 (R., 1966, v. 8, p. 426) which are of similar cultural status.

\section{SR-153. Green Fish Cave}

Modern

Charcoal from 0 to $10 \mathrm{~cm}$ level $\left(22^{\circ} 40^{\prime} \mathrm{S}\right.$ Lat, $30^{\circ} 45^{\prime} \mathrm{E}$ Long). Coll. and subm. by C. K. Cooke, Dir., Hist. Monuments Comm., Bulawayo, Rhodesia. Comment: sample too modern to date.

\section{SR-154. Green Fish Cave}

Modern

Charcoal from 2 to $3 \mathrm{~m}$ level. Comment: sample too modern to date.

\section{SR-117. Kinsale Farm, Lundi River}

$$
1410 \pm 95
$$

\section{A.D. 540}

Charcoal from test pit at 31 to $46 \mathrm{~cm}$ level $\left(20^{\circ} 18^{\prime} \mathrm{S}\right.$ Lat, $30^{\circ} 18^{\prime} \mathrm{E}$ Long). Coll. and subm. by K. R. Robinson. Comment: a report of pottery found at Kinsale led to further investigation of site. Pottery was of Gokomere tradition and so, date of A.D. 540 is very reasonable. More extensive excavations are hoped for in the future. 


\section{Lekkerwater Ruins series, Theydon}

Lekkerwater Ruins were excavated by S. Rudd, 7 Barons Court Greendale, Salisbury, Rhodesia. Site is one most $\mathrm{E}$ of Zimbabwe Ruin complex found in Rhodesia ( $18^{\circ} 05^{\prime} \mathrm{S}$ Lat, $31^{\circ} 42^{\prime} \mathrm{E}$ Long). Subm. by R. Summers.

SR-108. Lekkerwater Ruins

$560 \pm 120$

Charcoal from a main occupation layer. Comment: see Rudd (1968).

SR-109. Lekkerwater Ruins

A.D. 1300

$650 \pm 120$

Charcoal from foundation layer underlying some of the stone structures from site. Comment: probably contemporary with SR-108.

SR-124. Lekkerwater Ruins

A.D. 1510

$440 \pm 90$

Charcoal from base of wall. Comment: compare result with M-915 (R., 1961, v. 3, p. 123), earliest date for Zimbabwe Period IV.

SR-129. Lekkerwater Ruins

A.D. 1450

$500 \pm 95$

Sticks of pure charcoal from daga molds in ruins of a hut.

SR-181. Lekkerwater Ruins

$835 \pm 95$

Charcoal from floor sealed by paving stones. Comment: compare with M-914 (R., 1961, v. 3, p. 123), transition between Periods II and III at Zimbabwe.

$705 \pm 65$

SR-194. Lekkerwater Ruins

A.D. 1245

Charcoal from a destruction layer.

$505 \pm 45$

SR-197. Lekkerwater Ruins

A.D. 1445

Charred post in Floor 3.

SR-115. Mapela Hill

A.D. 1280

$670 \pm 95$

Charcoal from basal occupation layer 91 to $107 \mathrm{~cm}$ below surface (21 $1^{\circ} 44^{\prime} \mathrm{S}$ Lat, $28^{\circ} 48^{\prime} \mathrm{E}$ Long). Coll. and subm. by P. S. Garlake. Comment: sample from excavations to date major Leopard's Kopje site on Shashi R.; see Garlake (1968).

\section{SR-122. Mapela Hill}

$790 \pm 95$

Charcoal from sealed occupation horizon at depth $46 \mathrm{~cm}$ overlaying that at 91 to $107 \mathrm{~cm}$ in same excavation. Coll. and subm. by P. S. Garlake. Comment: dates major Leopard's Kopje Phase III site.

SR-120. Little Mapela Hill $490 \pm 90$

A.D. 1460

Sample from deposit accumulated at foot of free standing stone en- 
closure wall during construction (21 $1^{\circ} 43^{\prime} \mathrm{S}$ Lat, $28^{\circ} 48^{\prime} \mathrm{E}$ Long). Coll. and subm. by P. S. Garlake. Comment: pottery from dated deposit closely resembles Period IV wares of Zimbabwe, although other deposits in enclosure are of Leopard's Kopje Phase III.

\section{SR-131. Mount Hampden}

$4415 \pm 110$

Large carbonized timber $61 \mathrm{~cm}$ below ground level $2 \mathrm{~m}$ from grave containing Harari ware pottery $\left(17^{\circ} 42^{\prime} \mathrm{S}\right.$ Lat, $30^{\circ} 56^{\prime} \mathrm{E}$ Long). Sample possibly related to this grave, 1 of 3 excavated in same vicinity, though no visible occupation horizon connected the two. Coll. and subm. by P. S. Garlake. Comment: date proves that sample is not connected with graves, since very similar pottery to that found in grave was dated at A.D. 1280: Y-722 (R., 1960, v. 2, p. 58).

SR-165. Murahwa Hill, Umtali

Modern

Charcoal from bottom of occupation layer $\left(18^{\circ} 26^{\prime} \mathrm{S}\right.$ Lat, $32^{\circ} 53^{\prime} \mathrm{E}$ Long). Coll. by F. Bernhard, 127 3rd. St., Umtali, Rhodesia and subm. by P. S. Garlake. Comment: dated to determine if Murahwa Hill is Iron age settlement.

\section{SR-176. Murahwa Hill, Umtali}

$$
890 \pm 120
$$

Charcoal from Ziwa layer $3 \mathrm{~m}$ depth. Coll. by F. Bernhard and subm. by P. S. Garlake.

SR-134. Mwala Hill, Umguza River

$860 \pm 95$

Carbonized wood from hut remains (19 $51^{\prime} \mathrm{S}$ Lat, $28^{\circ} 32^{\prime} \mathrm{E}$ Long). Sample sealed under daga fragments. Coll. and subm. by K. R. Robinson. Comment: pottery from site suggests late Leopard's Kopje industry; date supports conclusion (Robinson, 1968).

\section{SR-146. Redcliff Lime Works}

$9560 \pm 270$ 7610 B.C.

Charred bone from $6 \mathrm{~m}$ level (19० $0^{\prime} \mathrm{S}$ Lat, $29^{\circ} 40^{\prime} \mathrm{E}$ Long). Coll. and subm. by C. K. Cooke. Comment: one of a series of dates being measured by several labs; comparative results not yet available.

\section{SR-173. Redcliff, Que Que}

$10,535 \pm 150$

Bone from bottom of bone concentration. Coll. and subm. by C. K. Cooke. Comment: bone layer contains a Bambata industry, apparently laid down over a very long period.

\section{SR-111. Rhodes-Inyanga Orchards, Inyanga $4950 \pm 120$ Natl. Park

Charcoal from trenches dug for water pipes in new experimental orchards ( $18^{\circ} 17^{\prime} \mathrm{S}$ Lat, $32^{\circ} 45^{\prime} \mathrm{E}$ Long). Coll. by C. B. Payne, and subm. by $\mathrm{O}$. West, both of Rhodes-Inyanga Orchards, Inyanga Natl. Park, Rho- 
desia. Comment: dated for general interest as there are many sites of archaeologic interest in Inyanga dist.

\section{SR-113. Rhodes-Inyanga Orchards, Inyanga $\quad 4020 \pm 95$ Natl. Park \\ 2070 B.C. \\ Charcoal from same horizon as SR-111. \\ SR-118. Sinoia Caves \\ $1300 \pm 95$}

Charcoal from occupation site at 51 to $66 \mathrm{~cm}$ depth $\left(17^{\circ} 20^{\prime} \mathrm{S}\right.$ Lat, $30^{\circ} 02^{\prime} \mathrm{E}$ Long), assoc. with Ziwa-type pottery which makes date of A.D. 650 acceptable. Coll. and subm. by K. R. Robinson. Comment: Robinson (1965). Date should mark beginning of occupation, assoc. with copper smelting.

\section{SR-164. Sinoia Caves}

$$
\begin{aligned}
& \mathbf{2 6 , 5 5 0}+\mathbf{7 5 0} \\
& 24,600 \text { B.c. }
\end{aligned}
$$

Charcoal from floor of cave $61 \mathrm{~cm}$ deep in well-stratified deposit $\left(17^{\circ}\right.$ $20^{\prime} \mathrm{S}$ Lat, $30^{\circ} 02^{\prime} \mathrm{E}$ Long). No assoc. artifacts to indicate age. Coll. and subm. by B. L. Holt, Dept. of Geol., Univ. of Rhodesia, Salisbury, Rhodesia. Comment: result will, hopefully date deposit.

SR-168. Sinoia Caves

$$
\begin{aligned}
& 26,110+740 \\
& 24,160 \text { в.c. }
\end{aligned}
$$

Charcoal from breccia at a depth ca. $122 \mathrm{~cm}$ below present floor. Sample assoc. with burnt bone and stone implements. Coll. and subm. by B. L. Holt.

\section{SR-136. Venzo Kopje}

$880 \pm 90$

Charcoal from shallow midden close to Shashani R. (21 $38^{\prime} \mathrm{S}$ Lat, $28^{\circ} 44^{\prime}$ E Long). Coll. and subm. by P. S. Garlake. Comment: settlement also contains Leopard's Kopje Phase III pottery; see Garlake (1966).

\section{SR-195. Zaka Ruin, Chiredzi River}

$255 \pm 55$

Charcoal from midden at 28 to $33 \mathrm{~cm}$ level $\left(20^{\circ} 22^{\prime} \mathrm{S}\right.$ Lat, $31^{\circ} 27^{\prime} \mathrm{E}$ Long). Coll. and subm. by P. S. Garlake. Comment: wall from this site is identical to outer wall of the Great Enclosure at Zimbabwe. This radiocarbon determination indicates that the ruin was built in the 15 th century, and may have been occupied for as long as 2 centuries.

\section{SR-196. Zaka Ruin, Chiredzi River}

$465 \pm 50$

Charcoal from the deposit at the foot of wall. Coll. and subm. by P. S. Garlake. Comment: see Garlake (1969). 


\section{SR-132. Blydefontein Shelter, Orange River Project $30 \pm 120$

Charcoal from $15 \mathrm{~cm}$ depth $\left(31^{\circ} 15^{\prime} \mathrm{S}\right.$ Lat, $25^{\circ} 6^{\prime} \mathrm{E}$ Long). Coll. by C. G. Sampson, School of Afr. Studies, Univ. of Cape Town, Cape Province, South Africa, and subm. by C. K. Cooke. Comment: result dates Late Stone age and is in correct sequence (Sampson, 1969).

\section{SR-142. Blydefontein Shelter}

$3090 \pm 100$

Charcoal from 31 to $36 \mathrm{~cm}$ depth. Coll. by C. G. Sampson and subm. by C. K. Cooke. Comment: date is in sequence and substantiates connection with Wilton culture from elsewhere in South Africa.

SR-152. Blydefontein Shelter

$3650 \pm 120$

1690 B.c.

Charcoal from 46 to $51 \mathrm{~cm}$ depth. Coll. by C. G. Sampson and subm. by C. K. Cooke. Comment: dates earliest apeparance of Wilton complex in shelter. Date is in correct sequence and confirms identity of industry.

SR-166. Bonteberg Shelter, Cape Peninsula

$2050 \pm 95$

100 B.C.

Shell from a layer containing pottery and lobster remains $\left(34^{\circ} 12^{\prime}\right.$ S Lat, $18^{\circ} 23^{\prime}$ E Long). Coll. and subm. by J. R. Grindley, Head Marine Biol. Dept., South Afr., Mus., Cape Town, South Africa. Comment: excavation of site provided unique series of remains of Cape rock lobster (Jasus lalandi). This appears to be the only case of Jasus occurring in archaeol. deposits, and so represents earliest known occurrence of this species (Beaumont 1963; Deacon 1965).

SR-167. Bonteberg Shelter

$4690 \pm 100$ 2740 B.C.

Marine shell Layer I. Coll. and subm. by J. R. Grindley. Comment: indicates total age of deposits.

SR-121. Glen Elliot Shelter, Orange River Project

Modern

Charcoal from bottom of deposit containing true "Smithfield B", known to be last cultural event in area ( $30^{\circ} 44^{\prime} \mathrm{S}$ Lat, $25^{\circ} 37^{\prime} \mathrm{E}$ Long). Sample gave result that was too young to be meaningful. Coll. and subm. by C. G. Sampson. Comment: dates 1st appearance of bushmen (Sampson, 1967).

\section{SR-130. Marion Island}

$2685 \pm 130$

735 в.C.

Dark brown peat from swamp 160 to $170 \mathrm{~cm}$ below surface $\left(46^{\circ} 50^{\prime}\right.$ $S$ Lat, $37^{\circ} 50^{\prime} \mathrm{E}$ Long). Coll. and subm. by E. M. van Zinderen Bakker, Univ. of the Orange Free State, Bloemfontein, South Africa. Comment: sample dated for correlation of climatic phase, culture and assoc. finds. Result was also required for comparison with pollen analysis. 


\section{SR-135. Marion Island}

$3340 \pm 160$

1390 B.c.

Black peat 190 to $200 \mathrm{~cm}$ below surface of swamp $\left(46^{\circ} 50^{\prime} \mathrm{S}\right.$ Lat, $39^{\circ}$ $50^{\prime}$ E Long). Coll. and subm. by E. M. van Zinderen Bakker. Comment: will hopefully correlate culture, climatic phase, and assoc. finds. Comparison with pollen analysis will be made later.

\section{SR-116. Rose Cottage Cave, Orange Free State}

Charcoal assoc. with artifacts thought to be Upper Magosian in date, (29 $15^{\prime} \mathrm{S}$ Lat, $27^{\circ} 30^{\prime} \mathrm{E}$ Long). Coll. and subm. by R. J. Mason, Univ. of Witwatersrand, Johannesburg, South Africa. Comment: dated to estimate age of assoc. Upper Magosian-style artifact assemblage for comparisons with similar assemblages from Rhodesia and Cape Province.

\section{SR-133. Zaayfontein Shelter, Orange River Project A.D. 1520}

$430 \pm 95$

Charcoal from 38 to $43 \mathrm{~cm}$ depth $\left(30^{\circ} 37^{\prime} \mathrm{S}\right.$ Lat, $25^{\circ} 31^{\prime} \mathrm{E}$ Long). Coll. and subm. by C. G. Sampson. Comment: dates lst definite appearance of pottery in shelter area; see Sampson (1967).

\section{SR-160. Zaayfontein Shelter}

$3270 \pm 115$

Charcoal from 10 to $11 \mathrm{~m}$ depth. Coll. and subm. by C. G. Sampson. Comment: dates end of Later Stone age at shelter. End of this phase at Zaayfontein Shelter overlaps beginning of Later Stone age at Blydefontein; see SR-132, -142, and -152, this date list.

\section{Zambia}

\section{SR-110. Dambwa, Livingstone}

$$
1290 \pm 120
$$

Charcoal from Dambwa site $\left(17^{\circ} 49^{\prime} \mathrm{S}\right.$ Lat, $25^{\circ} 51^{\prime} \mathrm{E}$ Long). Coll. and subm. by D. Phillipson, Natl. Monuments Comm., Zambia. Comment: see Samples SR-62 (R., 1966, v. 8, p. 425), SR-106, 96-98 (R., 1967, v. 9 , p. 385 and 386$)$.

\section{SR-123. Kalundu Mound, Kalomo}

$1495 \pm 95$

\section{A.D. 455}

Charcoal from sealed pit on Kalundu Mound ( $17^{\circ} 03^{\prime} \mathrm{S}$ Lat, $26^{\circ} 30^{\prime}$ E Long). Coll. by R. Inskeep, Univ. of Cape Town, South Africa, and subm. by D. Phillipson. Comment: confirms early date of SR-65 (R., 1966, v. 8, p. 425); see Phillipson (1968) and Inskeep (1962).

\section{SR-139. Kalundu Mound}

Charcoal from 2 to $2.3 \mathrm{~m}$ depth. Coll. by B. Fagan, and subm. by D. Phillipson. Comment: date falls within range of Kalomo culture dates (Fagan, 1967).

\section{SR-126. Leopard's Hill Cave, Lusaka}

$1415 \pm 125$

Charcoal, marking end of Late Stone age and is assoc. with a few sherds of Early Iron age (15 $36^{\prime} \mathrm{S}$ Lat, $28^{\circ} 43^{\prime}$ E Long). Coll. and subm. 
by D. Phillipson. Comment: in excellent agreement with Samples GX1012 and GX-1013 (Phillipson, 1968).

\section{SR-138. Leopard's Hill Cave}

Charcoal from 184 to $190 \mathrm{~cm}$ depth. Coll. and subm. by D. Phillipson. Comment: old age partly confirmed by other analyses, GX-0957 and UCLA-1291. Excavation at site appears to provide fairly complete Stone age succession for Lusaka area.

\section{SR-141. Leopard's Hill cave}

Charcoal from 31 to $38 \mathrm{~cm}$ depth. Coll. and subm. by D. Phillipson. Comment: further date in series which fits into pattern already established by previous 5 dates; SR-126 (this list) SR-38 (R., 1964, v. 6, p. 34), UCLA-1290, GX-0957, and UCLA-1291.

\section{E. Uganda}

\section{SR-137. Magosi Shelter}

Bone from a kunkar zone underlying a layer containing Wilton material. Coll. and subm. by G. Cole, Uganda Mus., Kampala, Uganda. Comment: see SR-92 (R., 1967, v. 9, p. 383), Wayland and Burkitt (1932), and Posnansky and Cole (1963).

\section{GEOLOGIC SAMPLES}

$$
37,200 \pm 3700
$$

\section{SR-85. Forno Da Cal, Maputo River, Moçambique 33,500 в.c.}

Sample consisting of small pebbles, calcareous concretions, mollusks, and oyster shell $\left(26^{\circ} 26^{\prime} \mathrm{S}\right.$ Lat, $32^{\circ} 39^{\prime} \mathrm{E}$ Long). Coll. and subm. by L. Barradas, Inst. de Investigaçao Cientifica de Moçambique, Lourenço Marques. Comment: further date in establishment of transgression of "Gamblian/Makalian" of Moçambique; see Sample SR-29 (R., 1966, v. 8, p. 428).

\section{Mondoro Tribal Trust series}

\section{SR-156. Carbonate concretions}

$12,760 \pm 220$

Carbonate nodules from clay 76 to $91 \mathrm{~cm}$ below surface $\left(18^{\circ} 21^{\prime} \mathrm{S}\right.$ Lat, $30^{\circ} 37^{\prime}$ E Long). Coll. and subm. by P. J. Watson, Univ. of Rhodesia, Salisbury. Comment: result required to date assoc. sodium-influenced soils, under study.

\section{SR-157. Carbonate nodules}

Carbonate nodules from clay $122 \mathrm{~cm}$ below surface.

SR-158. Carbonate nodules

Carbonate nodules from 198 to $231 \mathrm{~cm}$ depth.
$18,775 \pm 300$ 16,825 B.c.

$4322 \pm 180$ 2370 B.c. 
III. TREE SAMPLES

SR-54. Ocotea Usambarensis, Kawandoma, Vipya

Plateau, Malawi

$340 \pm 100$

A.D. 1610

Wood from outer shell of $\mathrm{E}$ African Camphor tree, central part of tree having been rotted or burnt $\left(12^{\circ} 02^{\prime} \mathrm{S}\right.$ Lat, $33^{\circ} 51^{\prime} \mathrm{E}$ Long). Coll. and subm. by J. Chapman, Commonwealth Forestry Inst., Oxford, England. Comment: date required for study on evergreen forests of Malawi.

\section{SR-56. Ocotea Usambarensis, Kawandoma}

$370 \pm 90$

Wood (12 $02^{\prime} \mathrm{S}$ Lat, $33^{\circ} 51^{\prime}$ E Long). Coll. and subm. by R. Drummond, Federal Herbarium, Salisbury, Rhodesia.

\section{SR-144. Umkondo Copper Mine, Bikita, Rhodesia A.D. 1630}

$320 \pm 90$

Wood from handle of hoe from base of ancient mine shaft ca. $9 \mathrm{~m}$ below surface $\left(20^{\circ} 20^{\prime} \mathrm{S}\right.$ Lat, $32^{\circ} 10^{\prime} \mathrm{E}$ Long). Coll. and subm. by $\mathrm{R}$. Summers. Comment: Portuguese reported similar mining techniques in area dated ca. 1510 to 1690 .

SR-112. Khaya Nyasica, Chirinda Forest, Rhodesia

Modern

Wood of a very common species that grows along water courses of Chirinda Forest and represents a fair cross section of larger trees $\left(20^{\circ} 28^{\prime}\right.$ $S$ Lat, $32^{\circ} 45^{\prime}$ E Long). Coll. and subm. by B. Goldsmith, Gungunyana Forest Reserve, Rhodesia. Comment: provides age span for Chirinda Forest.

\section{SR-151. Parinari sp., Chirinda Forest, Mount $190 \pm 110$ Salinda, Rhodesia \\ A.D. 1760}

Tree trunk at ground level, burnt and rotted to about half its width, from sound wood from approx. middle of stem and at ca. $61 \mathrm{~cm}$ above ground (20 25' S Lat, $32^{\circ} 41^{\prime} \mathrm{E}$ Long). Coll. and subm. by O. West. Comment: compare result with SR-112, this list.

\section{SR-149. Baobab Tree, Messina, South Africa}

$400 \pm 120$

Wood (Adonsonia digitata $L$ ) from tree $15 \mathrm{~m}$ in girth, from $2 \mathrm{~m}$ into tree and $2 \mathrm{~m}$ above ground $\left(22^{\circ} 18^{\prime} \mathrm{S}\right.$ Lat, $29^{\circ} 50^{\prime} \mathrm{E}$ Long). Coll. and subm. by G. L. Guy, Natl. Mus., Bulawayo, Rhodesia. Comment: one of a plot of trees whose growth rate is known for the last $35 \mathrm{yr}$, all the big trees are a few $\mathrm{cm}$ less in girth since they were first measured in 1931.

SR-150. Baobab Tree, Messina

Modern

Wood from same tree as SR-149, $107 \mathrm{~cm}$ from bark. Coll. and subm. by G. L. Guy. Comment: sample was too young to date.

\section{SR-48. Podocarpus falcatus, Lottering, South Africa \\ 980
A.D. 970 \\ $980 \pm 100$}

Heartwood from a large Outeniqua Yellowwood tree $\left(33^{\circ} 57^{\prime} \mathrm{S}\right.$ Lat, $23^{\circ} 47^{\prime} \mathrm{E}$ Long), from stem sec., ca. $305 \mathrm{~cm}$ above ground. Under bark 
girth of tree was $7 \mathrm{~m}$. Coll. and subm. by H. A. Luckhoff, Secretary for Forestry, Pretoria. Comment (H.A.L.): dated to compare age of these old trees, as determined by ring counts, with radiocarbon dating. Unfortunately, large areas of decay in the stem made a ring count impossible. A reasonably close correlation exists, however, between radiocarbon age of this tree and age of trees of similar diameter dated by ring counts.

\section{SR-49. Encephalartos transvenosis, Modjadji, NE Transvaal, South Africa \\ $450 \pm 90$}

Wood from sec. $61 \mathrm{~cm}$ above ground $\left(23^{\circ} 6^{\prime} \mathrm{S}\right.$ Lat, $31^{\circ} 00^{\prime} \mathrm{E}$ Long). Tree was $175 \mathrm{~cm}$ in girth. Coll. and subm. by S. H. Harper, Univ. of Rhodesia, Salisbury, Rhodesia. Comment (S.H.H.): Modjadji Palms were reputed of great but unknown age, and were in area when Modjadji Tribe moved into district some $300 \mathrm{yr}$ ago. Older members of Mojadji Tribe regarded trees as sacred and would not fell them.

\section{SR-60. Nyakimya Swamp, Fort Portal, Uganda}

$4070 \pm 120$

Wood from Nyakimya Swamp ( $0^{\circ} 39^{\prime} \mathrm{N}$ Lat, $30^{\circ} 16^{\prime} \mathrm{E}$ Long). Coll. by H. A. Osmaston, Dept. of Geog., Univ. of Bristol, Bristol, England, and subm. R. Summers. Comment: established date for explosion craters near Fort Portal.

\section{REFERENCES}

Beaumont, P., 1963, The Bonteberg shelter: a progress report: Jour. Sci. Soc., Univ. Cape Town, v. 6, p. 20-27.

Deacon, H. J., 1965, An annotated list of radiocarbon dates for sub-Saharan Africa: v. 5, Annals Cape Provincial Mus.

Fagan, B., 1967, Iron age cultures in Zambia, v. I: London.

Garlake, P. S., 1966, Iron age archaeol. in Shashi expedition: Rhodesian Schools Exploration Soc., Bulawayo, Rhodesia.

1967, Iron age burials at Mount Hampden near Salisbury, Rhodesia: Arnoldia, v. 3, no. 10 .

1968, Test excavations at Mapela Hill, near Shashi River, Rhodesia: Arnoldia, v. 3, no. 34. 1969, Iron age archaeol. in Bikita expedition: Rhodesian Schools Exploration Soc., Bulawayo, Rhodesia.

1970, Iron age site in the Urungwe District of Rhodesia: S. African Archaeol. Bull. XXV, v. 97, p. 25.

Grindley, J. R., Speed, E., and Maggs, T., 1970, The age of the Bonteberg shelter deposits, Cape Peninsula: S. African Archaeol. Bull. XXV, v. 97, p. 24.

Inskeep, R., 1962, Iron age sites in N. Rhodesia: S. African Archaeol. Bull. XVII, p. 136 180.

Phillipson, D., 1968, The Early Iron age in Zambia: Jour. African Hist., v. IX, p. 191211.

Posnansky, M. and Cole, G., 1963, Recent excavations at Magosi, Uganda: a preliminary report: Man, p. 133.

Ralph, E. K. and Michael, H. N., 1969, University of Pennsylvania radiocarbon dates XII: Radiocarbon, v. 11, p. 469-481.

Robins, P. A. and Swart, E. R., 1964, Southern Rhodesia radiocarbon measurements I: Radiocarbon, v. 6, p. 31-36.

Robinson, K. R., 1965, The Sinoia Caves, Lomagundi District, Rhodesia: Rhodesian Sci. Assoc. Proc. and Trans., v. 51, p. 131-155. 1967, Further work on Iron age sites in the Chibi District, S. Rhodesia, 1961-1963: Arnoldia, v. 3, no. 1.

1968, An examination of five iron age structures in the Umguza Valley,

$14 \mathrm{mi}$. N. of Bulawayo, Rhodesia: Arnoldia, v. 3, no. 35. 
Rudd, S., 1968, Preliminary report of excavations, 1963-66 at Lekkerwater Ruins, Tsindi Hill, Theydon, Rhodesia: Rhodesian Sci. Assoc. Proc. and Trans., v. 52, pt. 2, p. $38-50$.

Sampson, C. G., 1967, Excavations at Zaayfontein shelter, Norvalspont: N. Cape. Res. Natl. Mus., v. 2, 4, p. 41-124.

1969, The Smithfield Industrial Complex: Further field results: Natl. Mus. mem., no. 5 , in press.

Sheppard, J. G. and Swart, E. R., 1966, Rhodesian radiocarbon measurements II: Radiocarbon, v. 8 , p. $423-429$. 386

Stuiver, Minze and Suess, H. F., 1966, On the relationship between radiocarbon dates and true sample ages: Radiocarbon, v. 8, p. 534-540.

Wayland, E. J. and Burkitt, M. C., 1932, The Magosian culture of Uganda: Royal Anthropol. Inst. Jour., v. 62, p. 369-390. 